\title{
STRUKTUR PENDAPATAN DAN, STRUKTUR PENGELUARAN SERTA MEKANISME KOPING PETANI PEMILIK SEKALIGUS PENGGARAP DI KELURAHAN SETIANAGARA KECAMATAN CIBEUREUM KOTA TASIKMALAYA
}

\section{THE INCOME STRUCTURE AND EXPENDITURE STRUCTURE AND THE COPING MECHANISM OF THE OWNER FARMER AS WELLI AS SHARECROPPER FARMER IN SETIANAGARA VILLAGE, CIBEUREUM DISTRICT, TASIKMALAYA CITY}

\author{
Farhan Shidiq Sudama*, Trisna Insan Noor
}

Program Studi Agribisnis, Fakultas Pertanian, Universitas Padjadjaran *Email: farhan.sudama@gmail.com

(Diterima 12-10-2020; Disetujui 29-12-2020)

\begin{abstract}
ABSTRAK
Mekanisme koping adalah upaya yang dilakukan individu ataupun kelompok untuk mengatasi atau mengurangi berbagai tuntutan, beban ataupun tekanan sebagai sesuatu yang membebani dan mengganggu kelangsungan hidupnya. Petani padi sawah di Indonsia merupakan petani dengan mayoritas lahan sempit, dengan pendapatan yang kecil. Pendapatan yang kurang untuk memenuhi kebutuhan hidupnya dapat memberikan beban terhadap petani, sehingga petani melakukan mekanisme koping untuk mengatasinya, mekanisme koping yang dilakukan bisa beragam dari mencari pekerjaan lain hingga menjual lahan, petani yang menjual lahan inilah kemudian menyebabkan terjadi pengalihfungsian lahan pertanian. Penelitian ini bertujuan untuk mengetahui struktur pendapatan dan pengeluaran petani di Kelurahan Setianegara, Kecamatan Cibeureum, Kota Tasikmalaya, dan mekanisme koping yang dilakukan. Desain penelitian ini adalah deskriptif kuantitatif. Hasil analisis menunjukkan rata- rata pendapatan petani pemilik penggarap yang menjadi responden di Kelurahan Setianegara dalam satu tahun baru mampu memenuhi sekitar 97\% pengeluaran rata-rata. Untuk mengatasi kekurangan tersebut petani melakukan mekanisme koping, dengan menambah pendapatan, merubah pola konsumsi, menambah akses pangan, dan menambah akses untuk membeli pangan.
\end{abstract}

Kata Kunci: Mekanisme Koping, Struktur Pendapatan, Struktur Pengeluaran

\begin{abstract}
Coping mechanism is a strategy made by individuals or groups to overcome or reduce various pressures that interfere their own life. Lowland rice farmers in Indonesia are dominated by smallholder farmers, with small income. The income that has not been able to meet their needs can put a burden on them, to overcome their burdens they need to do coping mechanisms, there are various forms of coping mechanisms, it can be finding another job or hardly sell their own land, and causes conversion of agricultural land. This research aimed to determine the income structure and expenditure structure of lowland rice farmer's household at Setianagara Village, in Cibeureum District, Tasikmalaya City, and their coping mechanism as well. The design of this research is quantitative descriptive. The results showed that the farmer's average income at Setianagara Village in one year are only able to meet around 97\% of their average expenditure, for solving these problems, farmers adopted coping mechanisms, by increasing their income, changing consumption patterns, increasing food access, and increasing access to buying food.
\end{abstract}

Keywords: Coping Mechanism, Income Structure, Expenditure Structure 


\section{PENDAHULUAN}

Sektor pertanian di Indonesia memiliki peran yang sangat penting dalam mendukung perekonomian nasional, juga sebagai penyedia bahan pangan bagi masyarakat Indonesia, sehingga berbagai upaya pembangunan terus dilakukan guna mendorong sektor pertanian menjadi lebih baik, namun pada perjalanannya pembangunan pertanian selalu mendapatkan berbagai tantangan, salah satu permasalahan terbesar dari pembangunan pertanian adalah pertumbuhan akan permintaan pangan yang lebih cepat dari pada kemampuan produksinya, pertumbuhan permintaan pangan meningkat sejalan dengan pertumbuhan penduduknya. Thomas Malthus (1798) dalam teorinya menyatakan jika pertumbuhan produksi pangan cenderung tumbuh secara deret hitung, maka pertumbuhan penduduk cenderung tumbuh berdasarkan deret ukur. Menurut Maryunani (2018), pertumbuhan jumlah penduduk akan memberikan pengaruh terhadap keadaan sumberdaya alam dan lingkungan. Semakin banyak jumlah penduduk suatu wilayah maka semakin banyak pula kebutuhan yang harus dipenuhi oleh alam atau lingkungan.
Upaya yang dilakukan untuk menghadapi permasalahan tersebut kemudian melahirkan suatu konsep pembangunan berkelanjutan. Kaitannya dengan pembangunan berkelanjutan, berbagai klasifikasi mengenai nilai ekonomi lahan pertanian telah banyak dikemukakan, secara garis besar penilaian ekonomi lahan pertanian harus dilihat berdasarkan manfaat penggunaan (use values) dan manfaat bawaannya (intrinsic values). Aspek-aspek yang terkait dengan kedua manfaat tersebut, meliputi aspek ekonomi, lingkungan, dan sosial-budaya. Dari klasifikasi tersebut muncul konsep multifungsi pertanian yang mencakup berbagai fungsi pertanian yaitu sebagai penyedia lapangan kerja, pemelihara lingkungan, pelestari tradisi bahkan sebagai penyokong ketahanan pangan. Namun saat ini pertanian masih dianggap sebagai eksternalitas sehingga tidak diperhitungkan, pandangan masyarakat umum terhadap pertanian yang kurang, menyebabkan rendahnya penghargaan terhadap pertanian akibatnya sektor pertanian mudah dikalahkan oleh sektor lain. Hal tersebut berimbas pada penurunan angkatan kerja di sektor pertanian serta terjadinya alih fungsi lahan pertanian. 
Pertumbuhan lahan pertanian di Indonesia khususnya lahan sawah berlangsung sangat fluktuatif, sempat mengalami kenaikan tahun 2016 yaitu sebanyak 94.827 hektar, kemudian tahun 2017 mengalami penurunan sebanyak 25.126 hektar (BPS, 2018). Alih fungsi lahan pertanian saat ini berlangsung cepat, seolah tidak terkendali, desakan kebutuhan lahan untuk pembangunan terus meningkat, sementara luas lahan tidak bertambah dan terbatas. Akibatnya lahan pertanian secara terus menerus mengalami konversi lahan ke nonpertanian. Menurut Lestari (2009) proses alih fungsi lahan pertanian ke penggunaan nonpertanian disebabkan oleh faktor eksternal yang berkaitan dengan peningkatan penduduk ataupun tingkat ekonomi suatu wilayah, kemudian faktor internal yang berkaitan dengan keadaan sosial-ekonomi rumah tangga masyarakat dan juga faktor kebijakan pemerintah.

Berhubungan dengan kebijakan mengenai pertanian, pemerintah pun turut membuat kebijakan dengan fungsi utama untuk mendukung kemandirian, ketahanan, dan kedaulatan pangan nasional, Pemerintah Republik Indonesia telah menetapkan Undang-Undang Nomor 41 Tahun 2009 tentang
Perlindungan Lahan Pertanian Pangan Berkelanjutan $^{1}$. Meskipun undangundang perlindungan dan pengendalian pengerusakan dan degradasi lahan sudah ditetapkan, namun laju konversi lahan pangan di Indonesia tetap terjadi. Menurut Nuryatono (2017), desakan untuk memenuhi kebutuhan hidup keluarganya dan faktor penarik dari harga lahan yang tinggi kerap kali membuat petani lebih memilih menjual lahannya. Lahan tersebut kemudian beralih untuk pengembangan perkotaan, pembangunan infrastruktur dan fasilitas publik, perluasan kawasan pemukiman dan industri, yang mereduksi lahan-lahan pertanian pangan secara signifikan.

Badan Pusat Statistik

(BPS) menyebutkan luas lahan baku sawah terus menurun. Tahun 2017 Jawa Barat menjadi provinsi di Pulau Jawa dengan jumlah luas lahan baku sawah terbesar ketiga setelah Jawa Tengah dan Jawa Timur (BPS, 2018), namun luas lahan di Jawa Barat masih mengalami penurunan sebanyak 2.159 hektar tahun 2017 seperti pada Tabel 1 .

\footnotetext{
${ }^{1}$ Menurut UU No.41 Tahun 2009, Perlindungan Lahan Pertanian Pangan Berkelanjutan adalah sistem dan proses dalam merencanakan dan menetapkan, mengembangkan, memanfaatkan , membina, mengendalikan, dan mengawasi lahan pertanian pangan dan kawasannya secara berkelanjutan.

https://jdih.kemenkeu.go.id/fulltext/2009/41TAHU N2009UU.htm
} 
STRUKTUR PENDAPATAN DAN, STRUKTUR PENGELUARAN SERTA MEKANISME KOPING

PETANI PEMILIK SEKALIGUS PENGGARAP DI KELURAHAN SETIANAGARA

KECAMATAN CIBEUREUM KOTA TASIKMALAYA

Farhan Shidiq Sudama, Trisna Insan Noor

Tabel 1. Luas dan Pertumbuhan Lahan Sawah di Pulau Jawa Tahun 2015- 2017 (Hektar)

\begin{tabular}{llcccc}
\hline No & Provinsi & 2015 & 2016 & 2017 & $\begin{array}{c}\text { Pertumbuhan/Growth } \\
\text { 2017 over 2016 (\%) }\end{array}$ \\
\hline 1 & Jawa Timur & 1.091 .752 & 1.087 .018 & 1.081 .873 & $-0,47$ \\
2 & Jawa Tengah & 965.261 & 963.665 & 951.752 & $-1,24$ \\
3 & Jawa Barat & $\mathbf{9 1 2 . 7 9 4}$ & $\mathbf{9 1 3 . 9 7 6}$ & $\mathbf{9 1 1 . 8 1 7}$ & $\mathbf{- 0 , 2 4}$ \\
4 & Banten & 199.492 & 203.123 & 199.408 & $-1,83$ \\
5 & DI Yogyakarta & 53.553 & 53.985 & 51.341 & $-4,89$ \\
6 & DKI Jakarta & 650 & 581 & 571 & $-1,81$ \\
\hline
\end{tabular}

Sumber: Badan Pusat Statistika, 2018

Upaya yang telah dilakukan pemerintah daerah yaitu membuat Peraturan Daerah Provinsi Jawa Barat Nomor 27 Tahun 2010, yang seharusnya sudah mampu menahan laju alih fungsi lahan, namun pada kenyataannya kegiatan alih fungsi lahan masih terjadi.

Kota Tasikmalaya merupakan salah satu kota di Jawa Barat dengan luas lahan sawah terbesar diantara kota lainnya dengan luas lahan sawah sebesar 5.904 hektar tahun 2017 (BPS, 2018). Kota Tasikmalaya juga sudah merancang dan melakukan sosialisasi kebijakan perlindungan Lahan Pertanian Pangan Berkelanjutan (LP2B), namun Kota Tasikmalaya masih mengalami penurunan luas lahan sawah sebanyak 64 hektar sepanjang tahun 2015 hingga tahun 2017. Pemerintah sudah memasukan kebijakan tersebut dalam Peraturan Daerah Nomor 4 Tahun 2012 paragraf 7 pasal 49 ayat 2 dan terintegrasi dengan Rencana Tata Ruang Wilayah Tahun 2011-2031 yang termasuk kedalam rencana jangka panjang dan dilaksanakan di empat kecamatan yaitu Purbaratu, Cibeureum, Mangkubumi, dan Kawalu. Kecamatan Cibeureum adalah salah satu kecamatan yang termasuk dalam LP2B. Dan merupakan kecamatan dengan luas lahan ketiga terluas dan masih mengalami konversi lahan sebesar 5 hektar seperti pada Tabel 2.

Tabel 2. Perkembangan Luas Baku Lahan Sawah di Kota Tasikmalaya Tahun 20122016 (Hektar)

\begin{tabular}{clcccccc}
\hline No. & Kecamatan & 2012 & 2013 & 2014 & 2015 & 2016 & $\begin{array}{c}\text { Pengurangan } \\
\text { Luas Lahan }\end{array}$ \\
\hline 1. & Kawalu & 1.244 & 1.244 & 1.244 & 1.244 & 1.244 & - \\
2. & Cibeureum & $\mathbf{7 6 3 , 5}$ & $\mathbf{7 6 3 , 5}$ & $\mathbf{7 6 3 , 5}$ & $\mathbf{7 6 3 , 5}$ & $\mathbf{7 5 8 , 5}$ & $\mathbf{5}$ \\
3. & Purbaratu & 504 & 499 & 499 & 499 & 499 & 5 \\
4. & Mangkubumi & 1.134 & 1.134 & 1.134 & 1.134 & 1.132 & 2 \\
\hline & Jumlah & 6.017 & 5.999 & 5993 & 5.990 & 5.962 & 53 \\
\hline
\end{tabular}

Sumber : Badan Pusat Statistika, 2018 
Alih fungsi lahan di Kecamatan Cibeureum terus berkembang seiring dengan berkembangnya pembangunan di sektor perumahan (Prilly, 2018). Alih fungsi lahan berdampak terhadap kehidupan sosial ekonomi petani di daerah tersebut, dampak sosial ekonomi petani ditunjukkan dengan adanya ancaman terhadap kesempatan kerja petani yang semakin berkurang dalam sektor pertanian, semakin menurunnya pendapatan petani dan semakin sempitnya penguasaan lahan sawah oleh petani menyebabkan menjadi terancam dan mengganggu tingkat kestabilan ketahanan pangan keluarganya. Akibatnya petani harus bertahan dan menghadapi permasalahan yang ada, agar tetap mampu memenuhi kebutuhan hidup diri sendiri dan keluarganya.

Upaya yang dilakukan oleh petani untuk bertahan dan meminimalisir tekanan akibat masalah yang ada dikenal dengan nama mekanisme koping. Higgins dan Endler (1995) mendefinisikan mekanisme koping sebagai proses dan usaha dalam mengatur tuntutan atau tekanan dari eksternal atau internal yang diprediksi akan membebani hidup individu yang bersangkutan. Umumnya permasalahan yang dihadapi petani adalah permasalahan untuk dapat memenuhi kebutuhan hidup keluarganya, pendapatan petani yang terbatas membuat petani harus melakukan berbagai cara untuk dapat mencukupi kebutuhan keluarga, ditambah dengan potensi berkurangnya atau hilangnya lahan garapan membuat hasil produksi yang biasanya dikonsumsi ataupun dijual mengalami penurunan dan berdampak pada kestabilan tingkat ketahanan pangan keluarga, sehingga mekanisme koping yang tepat dapat menjadi upaya petani untuk menjaga kestabilan tingkat ketahanan pangan keluarganya, mekanisme koping yang diterapkan petani akan berbeda tergantung dari seberapa besar permasalahan dan tekanan yang diberikan oleh permasalahan yang ada.

\section{METODE PENELITIAN}

Penelitian ini menggunakan desain deskriptif kuantitatif dan menggunakan teknik penelitian survei. Objek yang diteliti dalam penelitian ini adalah mekanisme koping petani padi sawah yang berstatus sebagai pemilik sekaligus penggarap. Tempat penelitian ini berlokasi di Kelurahan Setianagara, Kecamatan Cibeureum, Kota Tasikmalaya, Jawa Barat. Penentuan 
tempat penelitian ini dilakukan secara sengaja (purposive).

Populasi dalam penelitian ini adalah petani pemilik sekaligus penggarap padi sawah di Kelurahan Setianagara, Kecamatan Cibeureum, Kota Tasikmalaya, Jawa Barat. Populasi yang didapatkan yaitu sebanyak 104 petani pemilik sekaligus penggarap padi sawah sehingga didapatkan ukuran sampel sebanyak 51 orang. Teknik pengambilan sampel dengan menggunakan teknik probability sampling yaitu simple random sampling.

Data penelitian menggunakan data primer dan sekunder. Teknik pengumpulan data melalui wawancara dan kuisioner. Data yang diperoleh dianalisis menggunakan analisis statistik deskriptif untuk memberikan penjelasan, interpretasi data dan informasi pada tabulasi data serta penjelasan mengenai tambahan informasi yang didapat di lapangan. dan juga menggunakan analisis struktur pendapatan dan struktur pengeluaran untuk melihat besar kontribusi pendapatan terhadap pengeluaran sebagai dorongan terjadinya mekanisme koping pada petani padi sawah.

Struktur pendapatan yang dimaksud adalah penyusun pendapatan keseluruhan yang diperoleh, juga bisa disebut dengan pendapatan rumah tangga. Pendapatan rumah tangga petani biasanya terdiri atas pendapatan yang diperoleh dari kegiatan usahatani ditambah dengan pendapatan yang berasal dari kegiatan di luar usahatani. Pendapatan luar usahatani adalah pendapatan yang diperoleh oleh kepala keluarga atau anggota keluarga lainnya sebagai akibat melakukan kegiatan di luar usahatani. Pendapatan usahatani merupakan pendapatan yang diperoleh dari selisih antara penerimaan dan biaya produksi (input) yang dihitung dalam periode bulan, tahun, maupun musim tanam. Secara sistematis, untuk menghitung pendapatan usahatani dapat ditulis sebagai berikut:

$\pi=\mathbf{T R}-\mathbf{T C}$

Keterangan:

$\pi=$ Keuntungan/pendapatans

$\mathrm{TR}=$ Total Revenue $($ Total Penerimaan $)$

$\mathrm{TC}=$ Total Cost $($ Biaya Produksi Total $)$

$\mathbf{T R}=\mathbf{P} . \mathbf{Y}$

Keterangan:

$\mathrm{TR}=$ Total Revenue (Total Penerimaan) $\mathrm{P}=$ Price $($ Harga $)$

$\mathrm{Y}=$ Jumlah produksi dalam periode tertentu

$\mathbf{T C}=\mathbf{F C}+\mathbf{V C}$ 
Keterangan:

$\mathrm{TC}=$ Total Cost (Biaya Produksi Total)

$\mathrm{FC}=$ Fixed Cost (Biaya Tetap)

$\mathrm{VC}=$ Variable Cost (Biaya Tidak Tetap)

Struktur pengeluaran adalah penyusun pengeluaran keseluruhan yang diperoleh oleh rumahtangga, terdiri atas pengeluaran pangan atau makanan dan pengeluaran non pangan. Menurut Amaliyah (2011) sistematika struktur pengeluaran dapat ditulis sebagai berikut: $\mathbf{T P}=\mathbf{P p}+\mathbf{P n}$

Keterangan:

$\mathrm{TP}=$ Total Pengeluaran (Rupiah)

$\mathrm{Pp}=$ Pengeluaran Pangan (Rupiah)

$\mathrm{Pn}=$ Pengeluaran Non Pangan (Rupiah)

\section{HASIL DAN PEMBAHASAN}

\section{Struktur Pendapatan}

Lahan pertanian merupakan salah satu faktor produksi utama dalam pertanian, adanya alih fungsi lahan dari lahan pertanian menjadi lahan non pertanian tentu akan berpengaruh dan bahkan menjadi ancaman terhadap keberlangsungan hidup petani padi sawah khususnya petani dengan penguasaan lahan sempit, dari penelitian di lapangan petani yang menjadi responden di Kelurahan Setianagara semuanya merupakan petani dengan penguasaan lahan sempit. Ancaman penurunan lahan garapan petani tentu akan menyebabkan berkurangnya penghasilan yang didapatkan dari usahatani, padahal walau tanpa ancaman tersebut penghasilan petani padi sawah umumnya belum mampu memenuhi pengeluaran keluarganya. Pendapatan rumah tangga petani biasanya terdiri atas pendapatan yang diperoleh dari kegiatan usahatani ditambah dengan pendapatan yang berasal dari kegiatan di luar usahatani.

\section{Tabel 3. Struktur Pendapatan Rumah Tangga Petani Responden}

\begin{tabular}{|c|c|c|c|}
\hline No. & Struktur Pendapatan Rumah Tangga & Nilai (Rp/tahun) & Persentase $(\%)$ \\
\hline 1. & Rata-rata Pendapatan Usahatani Padi & 5.319 .988 & 15 \\
\hline 2 . & Rata-rata Pendapatan Off Farm & 10.640 .000 & 31 \\
\hline 3. & Rata-rata Pendapatan Non Pertanian & 18.696 .470 & 54 \\
\hline & al Rata-rata Pendapatan Rumah Tangga & 34.929 .458 & 100 \\
\hline
\end{tabular}

Sumber: Analisis Data Primer (2020)

Tabel 3 menunjukan bahwa kontribusi terhadap struktur pendapatan petani responden selama satu tahun terbesar berasal dari pendapatan non pertanian yang didapatkan dari pendapatan anggota keluarga di luar dari kegiatan dalam sektor pertanian, sedangkan pendapatan yang berasal dari 
usahatani dalam satu tahun hanya berkontribusi sebanyak $15 \%$.

$$
\begin{aligned}
\mathbf{T R} & =\mathbf{P} . \mathbf{Y} \\
& =\mathrm{Rp} 5400 \times 772,05 \mathrm{Kg} \\
& =\mathrm{RP} .4 .169 .117 \\
\mathbf{T C} & =\mathbf{F C}+\mathbf{V C} \\
& =\mathrm{Rp} 51.000+\mathrm{Rp} .2 .344 .788 \\
& =\text { Rp2.395.788 } \\
\mathbf{\pi} & =\mathbf{T R}-\mathbf{T C} \\
& =4.169 .117-\mathrm{Rp} 2.395 .788 \\
& =\text { Rp1.773.329/ musim tanam }
\end{aligned}
$$

Berdasarkan perhitungan diatas diperoleh hasil bahwa rata-rata pendapatan petani responden di Kelurahan Setianagara sebesar $\mathrm{Rp}$ 1.773.329 dalam 1 kali musim tanam. Petani padi sawah di Kelurahan Setianagara biasanya maksimal hanya dapat bercocok tanam hingga 3 kali dalam satu tahun, dikarenakan lahan sawah mayoritas merupakan lahan tadah hujan. Sehingga dalam satu tahun petani responden di Kelurahan Setianagara mendapatkan rata-rata pendapatan dari usahatani padi sawah sebesar $\mathrm{Rp}$ 5.319.988.

Sumber pendapatan bagi rumah tangga petani di Kelurahan Setianagara juga berasal dari off-farm, dengan mayoritas bekerja sebagai buruh, baik itu buruh tani, buruh jahit ataupun buruh bangunan. Pada umumnya petani di Kelurahan Setianagara memilih untuk menambah pekerjaan agar mendapatkan pendapatan lebih karena bertanggung jawab sebagai seorang kepala keluarga. Ada sebanyak 28 petani dari 51 responden yang memilih untuk mencari pendapatan tambahan diluar kegiatan usahataninya. Rata-rata pendapatan offfarm dari 28 responden terhadap seluruh responden yaitu Rp .886 .670 per bulan dan rata-rata $\mathrm{Rp} 10.640 .000$ dalam satu tahun.

Rumah tangga petani yang berpendapatan rendah dan belum mampu mencukupi kebutuhan hidup, umumnya akan membuat anggota keluarganya bekerja, jumlah anggota keluarga yang bekerja tergantung pada banyaknya anggota keluarga dan pengeluaran di setiap keluarga petani responden di Kelurahan Setianagara dan jenis pekerjaan yang dilakukan cukup banyak dan bervariasi tergantung dari ketersediaan lahan pekerjaan dan beban pengeluaran keluarga tersebut, kebanyakan pekerjaan yang dilakukan adalah menjadi buruh bangunan, dengan rata-rata pendapatan keluarga petani responden sebesar $\mathrm{Rp}$ 18.696.470 dalam satu tahun. 
Struktur pendapatan rumah tangga petani padi sawah di Kelurahan Setianagara secata sistematis terdiri atas: rata-rata pendapatan usahatani padi sawah, rata-rata pendapatan off farm, dan rata-rata pendapatan non pertanian yang dihitung dalam 1 tahun.

$\mathbf{P}_{\mathrm{rt}}=\mathrm{P}$ on-farm usahatani padi $+\mathrm{P}$ offfarm + P non-farm

$=\operatorname{Rp} 5.319 .988+\operatorname{Rp} 10.640 .000+$ Rp18.696.470

$=\mathrm{Rp} 34.929 .458$

Berdasarkan hasil perhitungan diperoleh bahwa rata-rata pendapatan rumah tangga petani di Kelurahan
Setianagara dalam satu tahun adalah sebesar Rp 34.929.458 per tahun atau Rp 2.910 .788 per bulan.

\section{Struktur Pengeluaran}

Rata-rata pengeluaran rumah tangga petani responden di Kelurahan Setianagara untuk makanan dan bukan makanan adalah sebesar $\mathrm{Rp} 35,788,235$ dalam satu tahun dengan alokasi terbesar dari pengeluaran rumah tangga responden per tahunnya adalah untuk makanan sebesar $63 \%$ dan $37 \%$ untuk pengeluaran bukan makanan, selengkapnya bisa dilihat pada Tabel 4 .

Tabel 4 Struktur Pengluaran Rumah Tangga Petani Responden di Kelurahan Setianegara

\begin{tabular}{lcc}
\hline \multicolumn{1}{c}{ Jenis Pengeluaran } & Pengeluaran RT (Rp/Tahun) & Presentase (\%) \\
\hline Rata-rata Pengeluaran Makanan & $22,447,058$ & 63,0 \\
Rata rata Pengeluaran Bukan Makanan & $13,341,176$ & 37,0 \\
\hline Total Rata-rata Pengeluaran & $35,788,235$ & $\mathbf{1 0 0 . 0}$ \\
\hline
\end{tabular}

Sumber: Analisis Data Primer (2020)

Tabel 4 menunjukan bahwa struktur pengeluaran rumah tangga petani responden terdiri atas rata-rata pengeluaran makanan dan bukan makanan dengan kontribusi terbesar adalah pengeluaran makanan dengan nilai 63\%. Menurut Badan Pusat Statistika (2017), masyarakat dengan penghasilan tinggi cenderung akan melakukan pergeseran pola konsumsi dari pengeluaran makanan ke arah pengeluaran bukan makanan dan begitu pula sebaliknya, masyarakat dengan penghasilan rendah akan cenderung melakukan pengeluaran makanan yang lebih besar dari pada bukan makanan.

Pengeluaran pangan rumah tangga petani responden di Kelurahaan Setianegara terdiri atas rata-rata pengeluaran untuk konsumsi makanan tiap bulan oleh setiap rumah tangga, dan pengeluaran non pangan terdiri atas 
pengeluaran transportasi, biaya listrik, biaya pendidikan dan biaya non pangan lainnya, selengkapnya bisa dilihat pada Tabel 5.

Tabel 5. Pola Pengeluaran Rumah Tangga Petani Responden

\begin{tabular}{|c|c|c|c|}
\hline $\begin{array}{c}\text { No } \\
\text {. }\end{array}$ & Uraian & $\begin{array}{l}\text { Rata-rata Jumlah Pengeluaran } \\
\text { Seluruh Responden (Rp/thn) }\end{array}$ & $\begin{array}{c}\text { Persentase } \\
(\%)\end{array}$ \\
\hline \multirow[t]{6}{*}{1.} & Konsumsi Pangan & & \\
\hline & Karbohidrat & Rp. 6.734.118 & 19 \\
\hline & Protein & Rp. 6.285.176 & 18 \\
\hline & Lemak & Rp. 1.122.353 & 3 \\
\hline & Vitamin dan Mineral & Rp. 2.244.706 & 6 \\
\hline & Makanan Lainnya & Rp. 6.060.706 & 17 \\
\hline \multirow[t]{6}{*}{2.} & Konsumsi Non Pangan & & \\
\hline & Kebutuhan Sandang & Rp. 5.069.647 & 14 \\
\hline & Pendidikan & RP. 2.668.235 & 7 \\
\hline & Kesehatan & RP. 933.882 & 3 \\
\hline & Sosial & RP. 3.201 .882 & 9 \\
\hline & Kebutuhan Papan & Rp. 1.467.529 & 4 \\
\hline $\begin{array}{l}\text { Tota } \\
\text { dan }\end{array}$ & $\begin{array}{l}\text { rata-rata pengeluaran makanan } \\
\text { ukan makanan dalam } 1 \text { tahun }\end{array}$ & Rp. $35,788,235$ & 100 \\
\hline
\end{tabular}

Sumber: Analisis Data Primer (2020)

Tabel 5 menunjukkan bahwa pengeluaran untuk pangan berkontribusi besar terhadap total rata-rata pengeluaran rumahtangga petani, dengan kontribusi terbesar adalah konsumsi karbohidrat, dan dalam pengeluaran non pangan kontribusi terbesar adalah dari pengeluaran kebutuhan sandang.

Kontribusi Rata-rata pendapatan terhadap pengeluaran dapat menunjukkan seberapa besar kemampuan petani dapat memenuhi segala kebutuhan hidupnya dan keluarganya.

$$
\begin{aligned}
& \frac{\text { Rata }- \text { rata Pendapaatan RT }}{\text { Rata }- \text { rata Pengeluaran RT }} \times \mathbf{1 0 0} \% \\
& =\frac{\mathrm{Rp} 34.929 .458}{\mathrm{Rp} .35,788,235}=0.97 \times 100 \%=97 \%
\end{aligned}
$$

Rata-rata pendapatan petani responden hanya mampu memenuhi $97 \%$ rata-rata pengeluarannya, artinya masih terdapat defisit sebesar $3 \%$ dalam pemenuhan pengeluaran untuk memenuhi kebutuhan hidup dirinya dan keluarga artinya mereka masih harus mencari cara untuk keluar dari permasalahan tersebut. Sehingga konsep makanisme koping diperlukan oleh setiap keluarga untuk dapat mencukupi segala kebutuhannya. Umumnya mayoritas petani responden sebenarnya telah melakukan tindakan koping terhadap keberlangsungan hidupnya, yaitu dengan mencari sumber pemasukan lain selain dari pada usahatani, yaitu dengan pekerjaan 
sampingan (off-farm) ataupun membuat anggota keluarganya berperan mencari pemasukan yang lain non pertanian.

\section{Mekanisme Koping}

Mekanisme Koping pada petani seringkali luput dan tidak pernah terpikirkan secara sistematis, karena tidak adanya pengetahuan mengenai koping itu sendiri, padahal tanpa disadari setiap kali petani menghadapi masalah dan mencoba untuk meminimalisir beban yang ditimbulkan dari masalah tersebut bisa dikatakan bahwa petani telah melakukan mekanisme koping. Tanpa sadar petani telah melakukan mekanisme koping untuk menghadapi beban dari masalah yang ada, yaitu pemenuhan kebutuhan keluarga, sehingga ketika pendapatan yang didapatkan dari usahatani belum mencukupi kebutuhan, petani dengan secara naluri akan mencari pekerjaan lainnya, atau membuat anggota keluarga nya untuk bekerja.

Tabel 6. Mekanisme Koping Mendatangkan Pendapatan Petani Responden

\begin{tabular}{l|c|c|c|c|c|c}
\hline \multirow{2}{*}{ Mendatangkan Pendapatan } & \multicolumn{2}{|c|}{ Jumlah Responden } & Jumlah Responden & \multirow{2}{*}{ Total } & \multirow{2}{*}{$\%$} \\
\cline { 2 - 5 } & $\mathbf{I y a}$ & $\mathbf{\%}$ & Tidak & $\mathbf{\%}$ & & \\
\hline Mencari pekerjaan sampingan & 34 & $67 \%$ & 17 & $33 \%$ & & \\
Anggota keluarga bekerja & 38 & $75 \%$ & 13 & $25 \%$ & 51 & $100 \%$ \\
Menjual Aset & 4 & $8 \%$ & 47 & $92 \%$ & & \\
\hline
\end{tabular}

Sumber : Analisis Data Primer (2020)

Tabel 6, menunjukkan bahwa petani telah melakukan mekanisme koping untuk mendatangkan dan meningkatkan pendapatan yang ada untuk memenuhi kebutuhannya, ditunjukkan dengan sebanyak $67 \%$ petani responden memiliki pekerjaan sampingan dan $75 \%$ petani responden juga membuat keluarganya bekerja untuk meningkatkan pendapatan yang belum mencukupi.

Tabel 6 juga menunjukkan hanya 4 petani responden yang mendatangkan pendapatan dengan menjual aset mereka, dikarenakan aset yang dimiliki petani sangat terbatas, petani hanya memiliki aset rumah dan lahan sawah yang dimiliki, ditambah seluruh petani responden di Kelurahan Setianegara merupakan petani lahan sempit oleh karena itu menjual aset merupakan pilihan yang sulit dan bukan menjadi pilihan utama. Alasan empat petani responden menjual aset atau lahannya adalah karena seluruh pendapatan keluarganya belum mencukupi total pengeluaran keluarga tersebut, serta adanya tawaran harga yang cukup besar dari pembeli lahan tersebut. Adanya 
dorongan ekonomi dan juga faktor penarik dari harga yang ditawarkan membuat empat petani tersebut menjual lahan mereka. Lahan tersebut kemudian dibangun menjadi pesantren dan juga rumah, sehingga menyebabkan terjadinya pengurangan lahan pertanian di Kelurahan Setianegara akibat teralih fungsikannya lahan pertanian menjadi non pertanian.

Tabel 7. Mekanisme Koping Mengubah Pola Konsumsi Petani Responden

\begin{tabular}{l|cc|c|c|c|c}
\hline \multirow{2}{*}{ Merubah Pola Konsumsi } & \multicolumn{2}{|c|}{ Jumlah Responden } & \multicolumn{2}{|c|}{ Jumlah Responden } & \multirow{2}{*}{ Total } & \multirow{2}{*}{$\%$} \\
\cline { 2 - 5 } & Iya & $\mathbf{\%}$ & Tidak & $\mathbf{\%}$ & & \\
\hline Membeli makanan lebih murah & 20 & $39 \%$ & 31 & $61 \%$ & & \\
Mengurangi Porsi Makan & 21 & $41 \%$ & 30 & $59 \%$ & 51 & $100 \%$ \\
Mengurangi Jenis Makanan & 27 & $53 \%$ & 24 & $47 \%$ & & \\
\hline
\end{tabular}

Sumber: Analisis Data Primer (2020)

Tabel 7 menunjukkan bahwa 53\% dari total responden lebih memilih mengurangi jenis makanan, hal tersebut karena petani menilai bahwa mengurangi jenis makanan cenderung lebih efektif karena dapat mengurangi biaya agar lebih murah tanpa harus mengurangi porsi makan. Petani responden di Kelurahan Setianegara juga selalu menyimpan persediaan hasil produksi usahatani dalam bentuk beras untuk dikonsumsi keluarga, sehingga petani dapat mengganti jenis makanan dari makanan karbohidrat dengan lauk yang mengandung protein ataupun jenis makanan lainnya, dikarenakan sudah menjadi kebiasaan petani sebagai bentuk mitigasi ketika pendapatan tidak dapat mencukupi kebutuhan keluarga.

Tabel 8. Mekanisme Koping Menambah Akses Pangan Petani Responden

\begin{tabular}{|c|c|c|c|c|c|c|}
\hline \multirow[t]{2}{*}{ Penambahan Akses Pangan } & \multicolumn{2}{|c|}{ Jumlah Responden } & \multicolumn{2}{|c|}{$\begin{array}{c}\text { Jumlah } \\
\text { Responden }\end{array}$} & \multirow[t]{2}{*}{ Total } & \multirow[t]{2}{*}{$\%$} \\
\hline & Iya & $\%$ & Tidak & $\%$ & & \\
\hline Menerima bantuan pangan dari saudara & 37 & $73 \%$ & 14 & $27 \%$ & \multirow{4}{*}{51} & \multirow{4}{*}{$\begin{array}{c}100 \\
\%\end{array}$} \\
\hline Menerima bantuan pangan dari tetangga & 36 & $71 \%$ & 15 & $29 \%$ & & \\
\hline Menerima bantuan pangan dari pemerintah & 23 & $45 \%$ & 28 & $55 \%$ & & \\
\hline $\begin{array}{l}\text { Menerima bantuan pangan dari kelompok } \\
\text { tani }\end{array}$ & 13 & $25 \%$ & 38 & $75 \%$ & & \\
\hline
\end{tabular}

Sumber : Analisis Data Primer (2020)

Penambahan akses pangan dalam jangka waktu pendek dapat dilakukan dengan peminjaman, bantuan atau pencarian jenis pangan yang saat kondisi normal jarang dikonsumsi (Maxwell, 2001). Berdasarkan data petani responden lebih banyak melakukan mekanisme koping dengan menerima bantuan dari 
saudara, dengan jumlah 37 Keluarga, diikuti dengan menerima bantuan dari tetangga, dan terkecil adalah menerima bantuan dari kelompok tani, dikarenakan dalam kehidupan bermasyarakat petani sering kali tinggal dilingkungan yang berdekatan atau bertetangga dengan saudaranya, sehingga lebih memudahkan akses petani ketika menerima bantuan, sedangkan petani jarang menerima bantuan dari kelompok tani karena mereka lebih sering mendapatkan bantuan berupa alat bantu pertanian seperti bantuan cangkul, peminjaman traktor, pupuk, ataupun pestisida.

Tabel 9. Mekanisme Koping Menambah Akses Membeli Pangan

\begin{tabular}{l|c|c|c|c|c|c}
\hline \multirow{2}{*}{ Penambahan Akses Pangan } & \multicolumn{2}{|c|}{ Jumlah Responden } & \multicolumn{2}{|c|}{ Jumlah Responden } & \multirow{2}{*}{ Total } & \multirow{2}{*}{$\%$} \\
\cline { 2 - 5 } & Iya & $\mathbf{\%}$ & Tidak & $\mathbf{\%}$ & & \\
\hline Meminjam Uang & 47 & $73 \%$ & 4 & $27 \%$ & & \\
Berhutang Barang Konsumsi & 38 & $71 \%$ & 13 & $29 \%$ & 51 & $100 \%$ \\
Membeli barang dengan berhutang & 20 & $45 \%$ & 31 & $55 \%$ & & \\
Mengambil uang tabungan & 38 & $25 \%$ & 13 & $75 \%$ & & \\
\hline
\end{tabular}

Sumber : Analisis Data Primer (2020)

Tabel 9, menunjukkan bahwa sebanyak $73 \%$ dari seluruh responden melakukan peminjaman uang untuk memenuhi kebutuhan keluarganya dan yang terkecil yaitu membeli barang dengan berhutang yang hanya dilakukan oleh $45 \%$ keluarga dari total petani responden. Petani responden melakukan peminjaman uang kepada saudara ataupun tetanggannya, karena lebih mudah dilakukan akibat faktor kedekatan yang terjalin, petani responden juga lebih memilih berhutang dengan barang, karena lebih jelas pengembaliannya, berhutang barang artinya petani harus mengembalikan sesuai jenis dan jumlah barang yang dia pinjam, biasaya terjadi pada pada jenis bahan-bahan pokok.

\section{KESIMPULAN DAN SARAN}

Struktur pendapatan petani responden terdiri atas pendapatan usahatani, pendapatan off-farm dan pendapatan keluarga non pertanian dengan rata-rata pendapatan pertahun Rp34.929.458 dari 51 responden dan kontribusi terbesar adalah rata-rata pendapatan dari keluarga yang bekerja di sektor non pertanian dengan kontribusi sebesar 54\%. Sedangkan struktur pengeluaran petani terdiri atas pengeluaran non pangan dan pengeluaran pangan dengan rata-rata pengeluaran 


\section{STRUKTUR PENDAPATAN DAN, STRUKTUR PENGELUARAN SERTA MEKANISME KOPING \\ PETANI PEMILIK SEKALIGUS PENGGARAP DI KELURAHAN SETIANAGARA \\ KECAMATAN CIBEUREUM KOTA TASIKMALAYA \\ Farhan Shidiq Sudama, Trisna Insan Noor}

pertahun sebesar Rp.35.788.235 dari 51

responden. Dengan kontribusi terbesar berasal dari pengeluaran pangan sebanyak 63\%. Secara keseluruhan ratarata pendapatan 51 petani responden hanya berkontribusi sebesar $97 \%$ terhadap rata-rata pengeluarannya. Sehingga petani responden melakukan mekanisme koping untuk dapat mencukupi kebutuhannya.

Mekanisme koping dilakukan petani sebagai langkah untuk mencukupi kebutuhan hidupnya. Mekanisme koping yang dilakukan terdiri atas (1). mendatangkan pendapatan tambahan dengan melakukan pekerjaan sampingan, membuat anggota keluarga lain bekerja, dan menjual asset, asset yang dijual adalah lahan pertanian itu sendiri. (2) Merubah pola konsumsi dengan membeli makanan lebih murah, mengurangi porsi makan dan mengurangi jenis makanan. (3) Menambahkan akses pangan dengan cara menerima bantuan dari tetangga, menerima bantuan dari saudara, menerima bantuan dari pemerintah, dan menerima bantuan dari kelompok tani. (4) Menambah akses untuk membeli pangan dengan cara meminjam uang, berhutang barang konsumsi, membeli barang dengan berhutang dan mengambil uang tabungan.

\section{DAFTAR PUSTAKA}

Anggrayni, F.M. 2015. Pola konsumsi, Coping Strategy dan Ketahanan Pangan Rumah Tangga Peserta Urban Farming Pertanian dan Urban Farming Perikanan Kota Surabaya. Universitas Airlangga, Surabaya, Indonesia.

BPS. (2017). Pola Konsumsi Penduduk Jawa Barat. Provinsi Jawa Barat: Badan Pusat Statistik Provinsi Jawa Barat.

. (2018). Kota Tasikmalaya Dalam Angka 2018. Kota Tasikmalaya: Badan Pusat Statistik Kota Tasikmalaya. (2018). Provinsi Jawa Barat Dalam Angka 2018. Provinsi Jawa Barat: Badan Pusat Statistik Provinsi Jawa Barat.

. (2018). Statistika Data Lahan Pertanian 2018. Provinsi Jawa Barat: Badan Pusat Statistik Provinsi Jawa Barat.

Higgins, J.E. and Endler, N. 1995. Coping, Life Stress and Psychological and Somatic Distress. European Journal of Personality, 9, 253-270.

Lestari, T. 2009. Dampak Konversi Lahan pertanian Bagi Taraf Hidup Petani Bogor: Institut Pertanian Bogor.

Martunisa, Prilly. 2018. Faktor-Faktor Yang Mempengaruhi Alih Fungsi lahan di Kelurahan Kersaneraga, Kecamatan Cibeureum, Kota Tasikmalaya. Jurnal Rekayasa Hijau. Vol 2: (1)

Maryunani. (2018). Pengelolaan Sumberdaya Alam dan Pembangunan Ekonomi Secara Berkelanjutan. Malang: UB Press

Nuryartono et al. 2017. Land conversion and economic development in Jawa Barat Province: Trade off or Synergy. IOP Conference Series: Earth and Environmental Science. IOP Publishing. 